\title{
Protection of Destitute Women through Short Stay Homes in India
}

\author{
V. Sandhya Rani ${ }^{1}$, Dr. M. Trimurthi Rao ${ }^{2}$ \\ Research Scholar, Dept. of Sociology \& Social Work, Acharya Nagarjuna University, Nagarjuna Nagar, Guntur \\ Associate Professor, Dept. of Sociology \& Social Work, Acharya Nagarjuna University, Nagarjuna Nagar, Guntur
}

\begin{abstract}
Destitution has become a crucial subsidiary of family problems and issues in India. Destitute woman is considered to female without ample support who is abandoned, widowed or left alone without any care and support. Destitute women are facing several social disadvantages that either follow preceding ones or the issue of serious problems with awareness, affect, and behavior in our society. Short Stay Homes (SSHs) were set up with an objective to rehabilitate the women in distress into the main stream of society and empower them psychologically as well as with skills to lead independent normal life. Rehabilitation and follow-up are vital components of the scheme. This article discuss about the impact of crime and the status of destitute women and the role of Short Stay Homes in India.
\end{abstract}

Keywords: Destitute Women, Distress, Short Stay Homes (SSHs), Rehabilitation

\section{INTRODUCTION}

The destitute women facing multiple problems in the forms of vulnerability, gender-based violence, impact of climate change, lack of adaptive strategies, lack of access to financial services, and social exclusion. Due to lack of socioeconomic support, the domestic violence refers to violence against women plays a major part in the life of destitute women. Many people are facing hard financial times and the impact on mental health can be significant, moreover in the case of destitute women it is case sensitive. Lack of proper education, skills and abilities to execute a specified task might lead low levels of income financial problems. Sometimes, these problems can seem impossible to overcome, which is a clear indication for destitution. In other words Financial problem it is a situation where insufficient money to satisfy your need and wants, which leads you to stress.

\section{Women's Rights and Indian Constitution}

India's Constitution makers and our founding fathers were very determined to provide equal rights to both women and men. The Constitution of India is one of the finest equality documents in the world. It provides provisions to secure equality in general and gender equality in particular. Various articles in the Constitution safeguard women's rights by putting them at par with men socially, politically and economically. The Preamble, the Fundamental Rights, Directive Principles of State Policy (DPSP) and other constitutional provisions provide several general and special safeguards to secure women's human rights.

Preamble: The Preamble to the Constitution of India assures justice, social, economic and political; equality of status and opportunity and dignity to the individual. Thus it treats both men and women equal.

Fundamental Rights: The policy of women empowerment is well entrenched in the Fundamental Rights enshrined in our Constitution, for instance:

- $\quad$ Article 14 ensures to women the right to equality.

- $\quad$ Article 15(1) specifically prohibits discrimination on the basis of sex.

- $\quad$ Article 15(3) empowers the State to take affirmative action's in favour of women.

- Article 16 provides for equality of opportunity for all citizens in matters relating to employment or appointment to any office.

These rights being fundamental rights are justifiable in court and the Government is obliged to follow the same.

\section{NEED FOR THE STUDY}

A number of welfare programmes were designed to assist these destitute women and to provide relief and rehabilitation through vocational training and employment. Destitute women are acknowledged by many of Missionaries of Charities to provide psychological and physical treatment as well as counselling. Further many organisations were there provide short stay for destitute women. The projects in these organisations were determined to give skills training in tailoring \& embroidery, fashion designing courses as well as education facilities for sustainable livelihoods to destitute women. The main point of the homes to gives provisional sanctuary to upset women until they can either be 


\section{International Advanced Research Journal in Science, Engineering and Technology}

Vol. 5, Issue 11, November 2018

accommodated with the family or offered. This is the main message they give and their preparation just encourages this procedure. And there are home and rehabilitation centres for destitute women. As per the government rules destitute women can stay in the short stay home. Further after treatment and counselling they were rehabilitated through formal education and/or vocational training for survival. Objective of welfare services for destitute women be to rehabilitate them as normal citizens in the community they belong to. The programmes included ameliorative services of food, shelter, clothing, medical attention and curative services of education, pre-vocational training, vocational guidance, recreation and cultural development and citizenship education. Besides providing services for the destitute women, efforts are required to be made to prevent further spread of destitution among the future generations. This, however, covers larger question of raising the economic standards of living and providing preventive measures against destitution. In this framework the proposed paper examines the status of destitute women in India with reference to the Andhra Pradesh.

Objective of the Study: To depict the status of crimes against women and to analyze status of prevention measures and protection measures though SSH.

Method of the Study: This paper is completely based on secondary data, which was obtained from various books, journals, articles, published Government reports from the Department of Women and Child Development. Further secondary data also collected from various Census Reports, Statistical Abstract of Andhra Pradesh and Government Organizations, etc. simple tables, bar charts, compound annual growth rates and percentages were used for the analysis.

\section{ANNUAL GROWTH RATE OF CRIMES COMMITTED AGAINST WOMEN}

Annual Growth Rates (CAGR) of Crimes committed against women in India has been calculated for periods 1994 to 2004 and 2005 to 2015 were presented in the same Table 1. The result of CAGR shows that, sexual harassment cases have grown at 9.53 percent per year during 1994 to 2004 which has been declined to 1.09 percent during 2005-2015. And sexual abuse cases have increased at 2.09 percent of growth rate per annum during 1994 to 2004, while the growth has been raised during the period 2005 to 2015 with 8.89 percent growth rate per annum. But, the number of kidnapping cases has grown at -0.38 percent per year during 1994 to 2004, which has been increased to 14.12 percent growth during 2005 to 2015. The number of cases reported under Dowry Prohibition Act., during 1994-2004 has grown at 1.31 percent per annum, which reached to 10.83 percent of CAGR during 2005 to 2015 . Further, the crime of dowry death cases have grown at 2.64 percent during 1994to 2004, while it reduced to 0.95 percent during 2005 to 2015 . With regard to cruelty by husband the CAGR stud at 6.19 percent during 1994 to 2004, this was increased to 7.25 percent of CAGR during 2005 to 2015.

Table 1: Compound Annual Rate of Crimes Committed against Women

\begin{tabular}{|l|l|l|}
\hline \multirow{2}{*}{ Nature of Crime } & \multicolumn{2}{|l|}{ Crime rate in \% } \\
\cline { 2 - 3 } & $1995-\mathbf{2 0 0 4}$ & $\mathbf{2 0 0 5}-\mathbf{2 0 1 5}$ \\
\hline Rape & $\mathbf{2 . 1 6}$ & $\mathbf{6 . 9 3}$ \\
\hline Kidnapping \& Abduction & $\mathbf{- 0 . 3 8}$ & $\mathbf{1 4 . 1 2}$ \\
\hline Dowry Deaths & $\mathbf{2 . 6 4}$ & $\mathbf{0 . 9 5}$ \\
\hline Cruelty by Husband and Relatives & $\mathbf{6 . 1 9}$ & $\mathbf{7 . 2 5}$ \\
\hline Molestation & $\mathbf{2 . 0 9}$ & $\mathbf{8 . 8 9}$ \\
\hline Sexual Harassment/ Eve-Teasing & $\mathbf{9 . 5 3}$ & $\mathbf{1 . 0 9}$ \\
\hline Importation of Girls & $\mathbf{- 8 . 0 1}$ & $\mathbf{- 2 2 . 1 8}$ \\
\hline Immoral Traffic (Prevention) Act & $-\mathbf{4 . 2}$ & $-\mathbf{7 . 8 7}$ \\
\hline Indecent Representation of Women (Prevention) Act & $\mathbf{2 9 . 7 3}$ & $\mathbf{- 3 9 . 6 8}$ \\
\hline Dowry Prohibition Act & $\mathbf{1 . 3 1}$ & $\mathbf{1 0 . 8 3}$ \\
\hline Total & $\mathbf{3 . 4}$ & $\mathbf{7 . 9}$ \\
\hline
\end{tabular}

Source: Compiled from data by National Crime Records Bureau, Ministry of Home Affairs.

\section{State wise Ranking in Crimes against Women in India}

State wise number of total crimes against women in India has been presented in the Chart-1for the year 2015-16. Uttar Pradesh stands at $1^{\text {st }}$ place and West Bengal stands at $2^{\text {nd }}$ place in terms of total number of crime cases in India. However, Andhra Pradesh stands at $9^{\text {th }}$ place in terms of the total number of cases followed by Telangana with $10^{\text {th }}$ place. 


\section{International Advanced Research Journal in Science, Engineering and Technology}

Vol. 5, Issue 11, November 2018

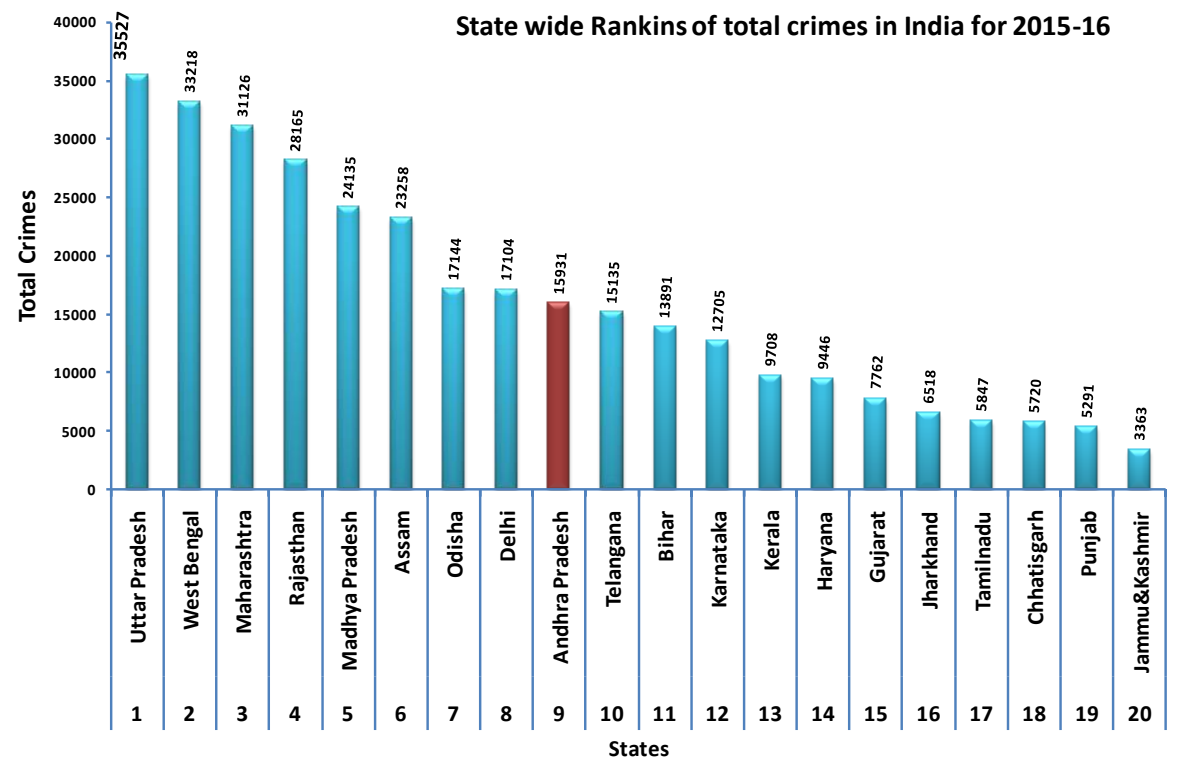

Crime wise distribution against Women in India

Chart 2.1 depicts crime wise percentage distribution of total crime against women in India. Out of the total crimes that have taken place in India, 36 percent of the cases are cruelty by husband, 26 percent of the cases are assault on women and 19 percent are kidnapping. Further, the rest of the crime cases are associated with crimes like sexual abuse (3\%), Dowry Prohibition Act (3\%) and dowry deaths (2\%). Chart 2.2 depicts the crime wise distribution of total number of cases in Andhra Pradesh for the year 2015-16. Chart reveals that 40 percent of the total crimes in Andhra Pradesh are associated to cruelty by husband, 30 percent of the cases are assault on women and 15 percent of the cases are sexual abuse. Further, 5 percent of the crime cases are related to kidnapping, 2 percent of the cases are related to Dowry Prohibition Act and 1 percent of the crime cases are dowry death in Andhra Pradesh.

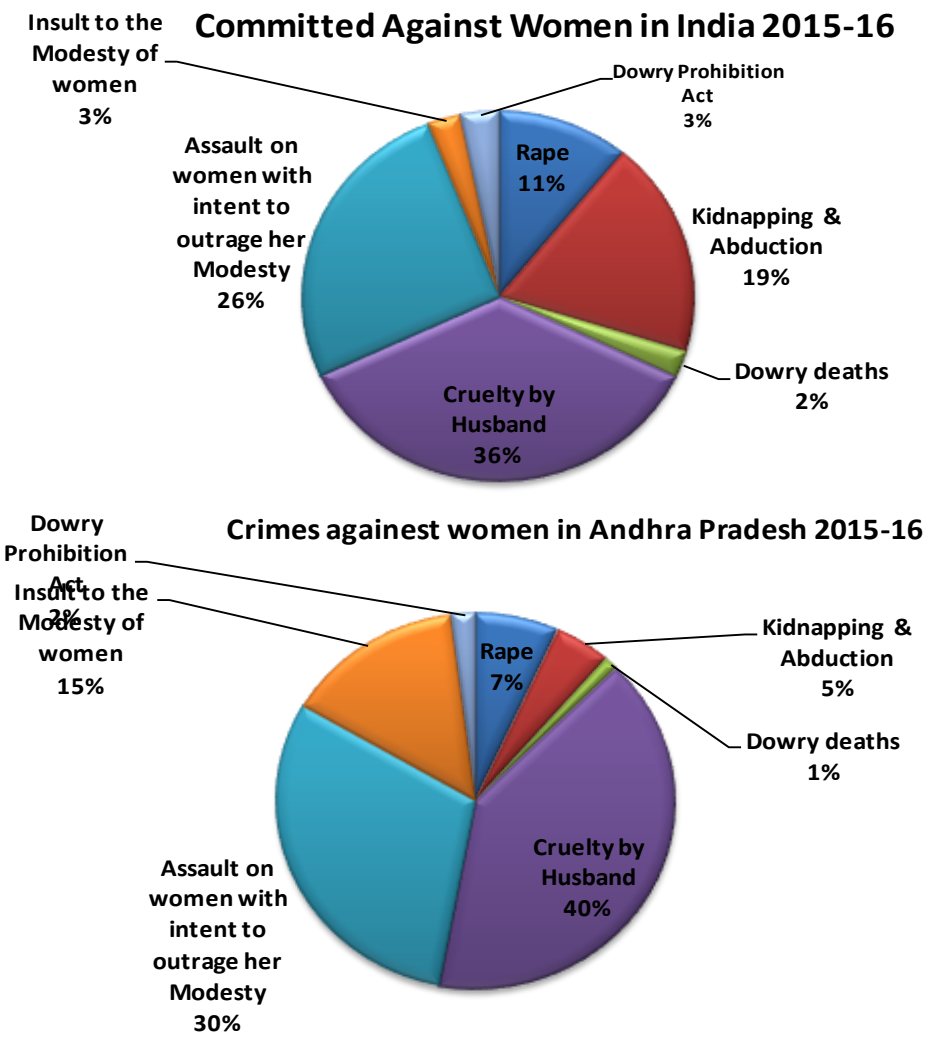

Distribution of crimes against Women in Andhra Pradesh

Chart 3 show the percentage share of crimes of Andhra Pradesh in total crime have taken in India. The percentage share of Andhra Pradesh in the India's kidnapping abduction crime is 1.15 during 2015-16. Andhra Pradesh occupied 25.33 percent in the total sexual abuse crime in India. Further, Andhra Pradesh has 8.42 percent share in internal traffic 


\section{International Advanced Research Journal in Science, Engineering and Technology}

Vol. 5, Issue 11, November 2018

prevention, 5.60 percent share in assault of women with intent and 5.40 percent share in cruelty by husband. Whereas, Andhra Pradesh has 3.06 percent share in India's crime type of Dowry Prohibition Act and 2.28 percent of dowry deaths during 2015-16.

\section{Percentage of crimes of Andhra Pradesh to India}

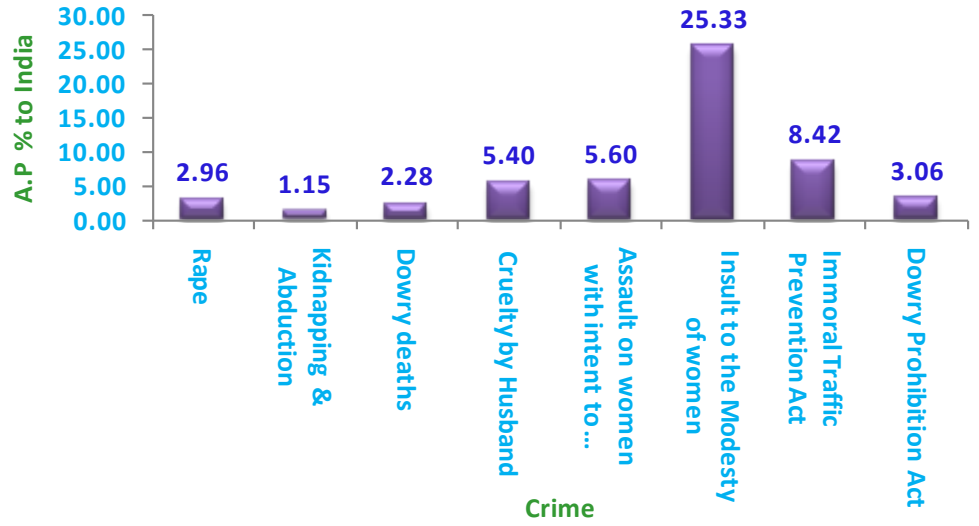

District wise incidence of Crimes against Women

District wise incidence of crimes against women has been presented in Table 2. Data shows that out of the total (961) rape cases reported in Andhra Pradesh, West Godavari stands at first place with 146 followed by Visakhapatnam with $122(84+38)$ and East Godavari with 120 cases $(85+35)$. Whereas, the data clearly shows that the number of rape cases are found to be relatively low in Rayalaseema region, which is 35 cases in Anantapuram, 32 cases in Kurnool and 28 cases in Kadapa. Out of the total (1066) kidnapping cases in Andhra Pradesh, Krishna District stands at first place with 153 cases followed by Nellore District with 153 cases and Guntur with 144 cases during 2014-15. Further, data shows that in Rayalaseema region most of the kidnapping cases have taken place in Ananthapuram District with 125 cases. The most number of sexual harassment cases have been reported in Guntur District with 1204 cases, followed by Krishna District with 1077 and East Godavari with 729 cases. Whilst, the least number of sexual harassment cases are reported in Prakasam District with 213 and Kadapa with 227 cases.

Table 2: District wise incidence of Crimes in A.P against Women during 2014 -15

\begin{tabular}{|l|l|l|l|l|l|}
\hline $\begin{array}{l}\text { Sl. } \\
\text { No. }\end{array}$ & District/ Circle & Rape & $\begin{array}{l}\text { Kidnapping Abduction } \\
\text { Of\& Others }\end{array}$ & $\begin{array}{l}\text { Dowry } \\
\text { Deaths }\end{array}$ & $\begin{array}{l}\text { Molestation\& Sexual } \\
\text { Harassment }\end{array}$ \\
\hline 1 & Srikakulam & 40 & 33 & 3 & 305 \\
\hline 2 & Vizianagaram & 47 & 27 & 8 & 552 \\
\hline 3 & Visakhapatnam City & 84 & 130 & 13 & 259 \\
\hline 4 & Visakhapatnam (R) & 38 & 24 & 4 & 186 \\
\hline 5 & East Godavari & 85 & 66 & 7 & 581 \\
\hline 6 & Rajahmundry & 35 & 15 & 3 & 148 \\
\hline 7 & West Godavari & 146 & 67 & 24 & 504 \\
\hline 8 & Krishna & 80 & 41 & 8 & 586 \\
\hline 9 & Vijayawada City & 64 & 42 & 10 & 491 \\
\hline 10 & Guntur (R) & 49 & 64 & 16 & 592 \\
\hline 11 & Guntur (U) & 40 & 84 & 12 & 612 \\
\hline 12 & Prakasam & 50 & 50 & 8 & 213 \\
\hline 13 & S.P.S Nellore & 58 & 153 & 14 & 500 \\
\hline 14 & Y.S.R & 28 & 27 & 16 & 227 \\
\hline 15 & Kurnool & 32 & 53 & 12 & 654 \\
\hline 16 & Anantapuram & 35 & 125 & 25 & 462 \\
\hline 17 & Chittoor(R) & 32 & 38 & 17 & 229 \\
\hline 18 & Tirupati (U) & 18 & 24 & 13 & 81 \\
\hline 19 & R.P.Vijayawada & - & 3 & 2 & 14 \\
\hline 20 & R.P. Guntakal & - & & - & - \\
\hline & Andhra Pradesh & $\mathbf{9 6 1}$ & $\mathbf{1 0 6 6}$ & $\mathbf{2 1 5}$ & $\mathbf{7 , 1 9 6}$ \\
\hline
\end{tabular}

Source: Compiled from data by National Crime Records Bureau, Ministry of Home Affairs.

\section{Incidence of major crimes against Women in Andhra Pradesh}




\title{
International Advanced Research Journal in Science, Engineering and Technology
}

\author{
Vol. 5, Issue 11, November 2018
}

Data related to incidence of major crimes like rape, abdication, dowry deaths, sexual harassments during 2006-2014 are presented in Table 3. Data shows that the sexual harassment and rape incidents are continuously rising. The number of sexual harassments committed in Andhra Pradesh is 2537 in 2006, and 5231 in 2010, further it reached to 7196 in 2014. Similarly, the number of rapes committed in Andhra Pradesh is 433 in 2006 and reached to 961 cases in 2014 . It became visible that the number of dowry deaths case is under control, which was 173 cases in 2006 and 273 cases in 2010, further it reduced to 215 cases in 2014. Further the data shows that major crimes committed against women in Andhra Pradesh are sexual harassment with 7196 cases in 2014 followed by kidnapping and abduction with 1066 cases and rape cases with 961 during 2014-15.

Table 3: Incidence of Major Cognizable Crimes (IPC) under different Heads in Andhra Pradesh for the Years From 2006 to 2014 (As on $31^{\text {st }}$ December)

\begin{tabular}{|l|l|l|l|l|l|l|}
\hline Year & Murder & Rape & $\begin{array}{l}\text { Women Kidnapping } \\
\text { Abduction }\end{array}$ & $\begin{array}{l}\text { Deaths } \\
\text { Dowry }\end{array}$ & $\begin{array}{l}\text { Harassment Molestation } \\
\text { and Sexual }\end{array}$ & Dacoity \\
\hline 2006 & 1,317 & 433 & 955 & 173 & 2,537 & 81 \\
\hline 2007 & 1,221 & 459 & 1000 & 203 & 2,536 & 86 \\
\hline 2008 & 1,217 & 570 & 973 & 204 & 2,820 & 53 \\
\hline 2009 & 1,133 & 526 & 885 & 213 & 3,043 & 49 \\
\hline 2010 & 1,293 & 714 & 1083 & 273 & 5,231 & 85 \\
\hline 2011 & 1,344 & 724 & 1153 & 246 & 5,390 & 74 \\
\hline 2012 & 1,392 & 702 & 942 & 239 & 5,200 & 62 \\
\hline 2013 & 1,205 & 746 & 1047 & 192 & 6,910 & 61 \\
\hline 2014 & 1,175 & 961 & 1066 & 215 & 7,196 & 75 \\
\hline
\end{tabular}

Source: Compiled from data by National Crime Records Bureau, Ministry of Home Affairs.

\section{REMEDIAL / REHABILITATION MEASURES}

\section{Role of SWADHAR Scheme}

The Central Social Welfare Board (CSWB) was set up by a Resolution of Government of India on $12^{\text {th }}$ August, 1953 with the objective of promoting social welfare activities and implementing welfare programmes for women and children through voluntary organizations. The Board has been making concerted efforts for empowerment of women through family counselling programme, Short Stay Home, Awareness Generation, Condensed Course of Education programme and other support services. The Board was registered as a charitable company in 1969 in order to give it a legal status. The State Social Welfare Boards were set up in 33 States and Union Territories to work together with Central Social Welfare Board in implementing programmes of the Board across the country. It is functioning as an interface between government and the voluntary sector.

\section{Organisation Structure}

The Board is governed by a General Body consisting of official and non-official members drawn from various sectors, Ministries and representatives from all the State Boards. The administrative functions of the Board are supervised by an Executive Committee. CSWB carried forward the exercise of strengthening the monitoring mechanism to ensure effective and qualitative implementation of programmes and delivery of services to the target groups. Based on a Workshop of all Field Officers and State Board Secretaries that was conducted at CSWB headquarters. The scheme of Short Stay Home was launched by the Government of India in 1969 to provide temporary shelter to women and girls who are being forced into prostitution; who as a result of family tension or discord are made to leave their homes without any mean of subsistence and have no social protection from exploitation and are facing litigation on account of marital disputes; who have been sexually assaulted and are facing the problem of re-adjustment in the family or society; who are victims of mental mal-adjustment, emotional disturbances and social ostracism, or who escape from their homes due to family problems, mental or physical torture. Who escape from their homes due to family problems, mental or physical torture and need shelter, psychiatric treatment and counselling for their rehabilitation and readjustment in family and society.

The Second, Third, Fourth and Fifth Plans, including the four years of plan holiday that preceded the Fourth Plan continued the same approach for the welfare of women. The concept of women's development was mainly 'welfare' oriented and was clubbed with other categories of welfare such as the old and the disabled. The schemes of condensed Course of Education and Women and Socio Economic Programmes were introduced during the Second Plan (1956-61) and that of Working Girl's Hostel and Short Stay Homes in the Fourth Plan (1969-74). These were the only women specific schemes of the department during the first 28 years of planning history. This scheme was earlier being implemented directly by the Department of Women and Child Development through the Non-Governmental Organisations. While the power to sanction new Homes still vests with the department, the responsibility of supervision 


\title{
International Advanced Research Journal in Science, Engineering and Technology
}

\author{
Vol. 5, Issue 11, November 2018
}

and monitoring of the existing Homes and release of fund to the NGOs running the Homes have been delegated to the Central Social Welfare Board from April, 1999. The financial norms and guidelines of the scheme of Short Stay Home has also been revised in June 1999 to make it more relevant and effective. Following categories of women and girls are eligible for staying in the Home:

1) Those who are being forced into prostitution.

2) Those who as a result of family tension or discord are made to leave their Homes without any means of subsistence and have no social protection from exploitation and facing litigation on account of marital disputes.

3) Those who have been sexually assaulted and are facing the problem of re-adjustment in the family or society.

4) Victims of mental mal-adjustment, emotional disturbances and social ostracism.

5) Those who escape from their Homes due to family problems, mental/physical torture and need shelter, psychiatric treatment and counselling for their rehabilitation and re-adjustment in family/society.

Short Stay Homes are set up with an objective to rehabilitate the women in distress into the main stream of society and empower them psychologically as well as with skills to lead independent normal life. Rehabilitation and follow-up are vital components of the scheme. Women are looked after through follow-up even after they are relieved from the Short Stay Home.

The Short Stay Home (SSH) provides accommodation, medical care, counselling, occupational therapy, social facilitation in adjustment, educational, vocational recreational and cultural activities etc. according to individual requirements. The period of stay normally extends from 6 months to 3 years. Temporary shelter will be provided to these women and girls from six months to three years with case work, counselling services, medical care and psychiatric treatment, skill development training, education, vocational and rehabilitative services are provided in the Short Stay Home. Special attention has been given to provide shelter and assistance to the women affected due to natural/manmade calamities. Homes were also set up in the cyclone affected areas in Orissa, in Jammu \& Kashmir to help the women affected due to Kargil War, in earthquake affected areas of Gujarat and in Tsunami affected areas of Tamil Nadu and Andaman \& Nicobar Islands. Short Stay Home has also been set up in Chennai for the women and girls rescued from the brothels and suffering from HIV positive. 9.25 Short Stay Homes are regularly monitored through the field machinery of CSWB, which is posted in all the States. Central Board, Central Govt. and State Govt. officials also conduct the inspection of Short Stay Homes. Continuation grant to Short Stay Homes is considered on the basis of inspection reports received regularly from State Boards and on the basis of documents like quarterly progress reports, audited accounts etc. submitted by voluntary organizations. Voluntary organizations also send request for continuation of grant. Each case is examined on merit. State wise amount sanctioned/released and beneficiaries covered during 2004-05 and 2005-06. The objectives of the programme are as under:

$>\quad$ To provide services to women and girls in need of special care and protection and to ensure that proper care is provided till they are rehabilitated.

To provide Crisis Intervention Services.

$>\quad$ To provide referral services like Short Stay Home, free Legal aid, Police assistance, Counselling, Hospitalization etc.

$>\quad$ To arrange suitable rehabilitation services for the target group.

$>\quad$ To provide counselling.

$>\quad$ Awareness, opinion building and documentation.

$>\quad$ Documentation of the type of cases being registered to understand the trends and magnitude of the problem in society.

Special attention has been given to extend assistance to women affected by natural calamities. Women's Helplines were given funds for providing services in Tsunami affected areas of Pondicherry and Andaman \& Nicobar Islands. About $60 \%$ homes are functional in six major states of Andhra Pradesh, Maharashtra, Orissa, Tamil Nadu, Uttar Pradesh and West Bengal. The focus during the period was to strengthen monitoring mechanism to ensure quality services to the needy women through genuine organizations. Therefore, during 2010- 11 continuation grants have been approved for 294 homes; 14 Homes have been closed as their performance was not reported to be according to the norms of the scheme; notices have been issued to 21 Homes giving them an opportunity for improving their services and the remaining cases are under process.

\section{Merger of SWADHAR Scheme with Short Stay Home (SSH) Programme}

As the objective of SWADHAR scheme and Short Stay Homes is similar, it has been decided to merge both the schemes and start a new scheme called SWADHAR GREH from the 2011 financial year. An EFC note in this regard has been circulated by the Ministry. Therefore, setting up of new Homes has not been considered during the year. The Short Stay Home scheme being implemented through Central Social Welfare Board is similar in nature as the Swadhar Scheme. Both the schemes - Swadhar and Short Stay Home are proposed to be merged to a new scheme i.e., 'Swadhar Greh' for which EFC note has been circulated on 31st January, 2011. Under the proposed Swadhar Greh Scheme, the norms for food, clothing, medical care etc. as well as honoraria for the staff are being revised to make them more 


\section{International Advanced Research Journal in Science, Engineering and Technology}

Vol. 5, Issue 11, November 2018

realistic as per present living standards. The scheme aims to set up a Swadhar Greh in every district. The scheme of Swadhar Greh had been circulated to all the concerned on 4-10-2011. All the state Governments have been requested to review the performance of the existing shelter homes for its conversion to Swadhar Greh. 'Swadhar Greh' revised financial norms in order to reach out to those women who are victims of different circumstances and are in need of institutional support for rehabilitation so that they could lead their life with dignity. It is also envisaged to set up at least one Swadhar Greh in every district. The scheme is proposed to be implemented as a component of the Umbrella Centrally Sponsored Scheme on Women Protection and Empowerment during the $12^{\text {th }}$ Plan period.

Funds sanctioned and beneficiaries covered under SSH program (2001-02 to 2015-16)

An amount of Rs.2038.95 crore has been sanctioned to maintain 247 Short stay homes and provided 23712 destitute women shelter during 2016. The number of SSH are decaling from 384 in 2009 to 283 in 2015. Whereas, number of destitute women who provided shelter is 27648 in 2009 and 27168 in 2015 which is not a major decline. Further, the number of home were reduced to 247 and as beneficiaries declined to 23712 in 2016.

Table 4: Funds sanctioned, released and beneficiaries covered under SSH program during 2001 - 02 to 2015 - 16

\begin{tabular}{|l|l|l|l|l|}
\hline Year & $\begin{array}{l}\text { Sanctioned Amount } \\
\text { (In Crores) }\end{array}$ & $\begin{array}{l}\text { Released } \\
\text { amount }\end{array}$ & $\begin{array}{l}\text { Number } \\
\text { of SSH }\end{array}$ & $\begin{array}{l}\text { Number } \\
\text { Beneficiaries }\end{array}$ \\
\hline 2002 & 1284.00 & 659.28 & 250 & - \\
\hline 2003 & 1784.00 & 751.76 & 289 & - \\
\hline 2004 & 1585.90 & 1447.19 & 341 & - \\
\hline 2005 & 1019.00 & 1019.57 & 272 & 16900 \\
\hline 2006 & 1650.00 & 1649.45 & 339 & - \\
\hline 2007 & 1984.19 & 1696.71 & 349 & 24120 \\
\hline 2008 & 1672.87 & 1499.74 & 270 & 19440 \\
\hline 2009 & 2728.89 & 1704.42 & 384 & 27648 \\
\hline 2010 & 2371.35 & 1734.43 & 336 & 24192 \\
\hline 2011 & 2235.13 & 1686.31 & 294 & 19961 \\
\hline 2012 & 3330.00 & 3330.00 & 320 & 19949 \\
\hline 2013 & 2658.87 & 2860.05 & 306 & 22032 \\
\hline 2014 & 3355.58 & 2987.31 & 307 & 22104 \\
\hline 2015 & 1563.34 & 1563.34 & 283 & 27168 \\
\hline 2016 & 2038.95 & 1321.51 & 247 & 23712 \\
\hline
\end{tabular}

Sate wise funds sanctioned and beneficiaries covered under SSH programme during 2001-02 \& 2015-16

State wise details of funds sanctioned amount, released amount, total number of SSHs and number of beneficiaries has been presented in Table 4. Details of funds sanctioned, released and beneficiaries covered under the SSH programme during 2001-02 and 2015-16 has been presented in Table 4. In India, about 23712 persons are benefited in SSHs programme during 2015-16. Out of the total beneficiaries, most number of destitute women are joined and benefited in the states of Tamil Nadu with 3072 persons (13.0 percent to total), followed by Odisha and Uttar Pradesh with 2592 persons each (10.9\%). Further, number of beneficiaries under SSH is also found to be high in the states like Maharashtra with 2463 persons (10.5 percent), Paschim Bangal with 2400 persons (9.9\%t) and Karnataka with 1824 persons ( 9.3 percent). Altogether, these 6 states account for 63 percent alone to the total number of beneficiaries under Short stay homes in India during 2015-16. The number of Short stay homes in operation is 302 during 2015-16, however, the financial assistance is provided to 247 homes for the maintenance. Out of the total 302 homes, most of the Short stay homes are located in the six states of Uttar Pradesh (34), Tamil Nadu (32), Odisha (32), Maharashtra (32), Paschim Bangarl (30) and Karnataka (28). These 6 states account for 63 percent alone to the total number of Short stay homes in India during 2015-16. During 2015-16, about 16 SSHs are located in Madhya Pradesh state, 15 SSHs are in Andhra Pradesh state, 15 SSHs are in Telangana state and 13 SSHs are located in Bihar state.

Table 5: State wise funds sanctioned/released and beneficiaries covered under the scheme of Short Stay Home Programme for the year 2015-16

\begin{tabular}{|l|l|l|l|l|l|l|l|}
\hline $\begin{array}{l}\text { Sl. } \\
\text { No. }\end{array}$ & Name of the State & $\begin{array}{l}\text { Homes } \\
\text { No. of }\end{array}$ & $\begin{array}{l}\text { No. of sanctioned } \\
\text { Homes }\end{array}$ & $\begin{array}{l}\text { Sanctioned } \\
\text { Amount }\end{array}$ & $\begin{array}{l}\text { (65\%Amount } \\
\text { sanctioned released }\end{array}$ & $\begin{array}{l}\text { Liabilities } \\
\text { released Past }\end{array}$ & $\begin{array}{l}\text { No. } \\
\text { beneficiaries }\end{array}$ \\
\hline 1 & Andhra Pradesh & 15 & 12 & 98.30 & 63.90 & 88.30 & 1152 \\
\hline 2 & Assam & 12 & 12 & 98.30 & 63.90 & 42.61 & 1152 \\
\hline 3 & A \& N Islands & 0 & 0 & 0 & 0 & 0 & 0 \\
\hline 4 & Arunachal Pradesh & 1 & 1 & 8.19 & 5.32 & 6.33 & 96 \\
\hline 5 & Bihar & 13 & 10 & 81.92 & 53.25 & 18.87 & 960 \\
\hline
\end{tabular}


International Advanced Research Journal in Science, Engineering and Technology

Vol. 5, Issue 11, November 2018

\begin{tabular}{|l|l|l|l|l|l|l|l|}
\hline 6 & Chandigarh & 1 & 1 & 8.54 & 5.55 & 3.99 & 96 \\
\hline 7 & Chhattisgarh & 3 & 2 & 16.38 & 10.65 & 8.39 & 192 \\
\hline 8 & Dada \& Nagar & 0 & 0 & 0 & 0 & 0 & 0 \\
\hline 9 & Delhi & 2 & 2 & 17.77 & 11.55 & 1.18 & 192 \\
\hline 10 & Gujarat & 3 & 1 & 8.19 & 5.32 & 3.81 & 96 \\
\hline 11 & Goa & 1 & 1 & 8.19 & 5.32 & 0 & 96 \\
\hline 12 & Haryana & 1 & 0 & 0 & 0 & 0 & 0 \\
\hline 13 & Himachal Pradesh & 0 & 0 & 0 & 0 & 0 & 0 \\
\hline 14 & Jharkhand & 1 & 0 & 0 & 0 & 0 & 0 \\
\hline 15 & Jammu \& Kashmir & 1 & 1 & 8.19 & 5.32 & 2.44 & 96 \\
\hline 16 & Karnataka & 28 & 19 & 157.72 & 102.52 & 79.22 & 1824 \\
\hline 17 & Kerala & 5 & 3 & 24.58 & 15.97 & 6.07 & 288 \\
\hline 18 & Lakshadweep & 0 & 0 & 0 & 0 & 0 & 0 \\
\hline 19 & Madhya Pradesh & 16 & 10 & 81.92 & 50.68 & 64.05 & 960 \\
\hline 20 & Maharashtra & 32 & 26 & 214.37 & 139.34 & 82.57 & 2496 \\
\hline 21 & Manipur & 5 & 5 & 40.96 & 26.62 & 34.72 & 480 \\
\hline 22 & Mizoram & 1 & 1 & 8.19 & 5.32 & 0 & 96 \\
\hline 23 & Meghalaya & 0 & 0 & 0 & 0 & 0 & 0 \\
\hline 24 & Nagaland & 1 & 1 & 8.19 & 5.32 & 0 & 96 \\
\hline 25 & Odisha & 32 & 27 & 221.18 & 143.77 & 113.59 & 2592 \\
\hline 26 & Paschim Bengal & 30 & 25 & 208.26 & 135.37 & 66.61 & 2400 \\
\hline 27 & Punjab & 2 & 2 & 16.73 & 10.88 & 1.56 & 192 \\
\hline 28 & Puducherry & 1 & 1 & 8.19 & 5.32 & 0 & 96 \\
\hline 29 & Rajasthan & 3 & 3 & 25.61 & 16.65 & 6.55 & 288 \\
\hline 30 & Sikkim & 1 & 1 & 8.19 & 5.32 & 3.99 & 96 \\
\hline 31 & Tamil Nadu & 32 & 32 & 263.52 & 171.29 & 92.08 & 3072 \\
\hline 32 & Telangana & 15 & 12 & 101.77 & 66.15 & 45.16 & 1152 \\
\hline 33 & Tripura & 4 & 4 & 32.77 & 21.30 & 9.33 & 384 \\
\hline 34 & Uttar Pradesh & 34 & 27 & 221.87 & 142.99 & 101.17 & 2592 \\
\hline 35 & Uttrakhand & 6 & 5 & 40.96 & 26.62 & 1.70 & 480 \\
\hline & Total & $\mathbf{3 0 2}$ & $\mathbf{2 4 7}$ & $\mathbf{2 0 3 8 . 9 5}$ & $\mathbf{1 3 2 1 . 5 1}$ & $\mathbf{8 8 4 . 2 9}$ & $\mathbf{2 3 7 1 2}$ \\
\hline
\end{tabular}

State wise rankings in the average Number of beneficiaries per SSH during 2015-16

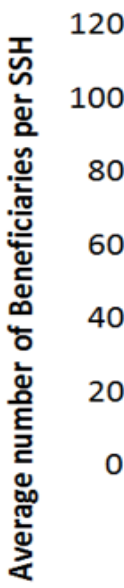

969696

$\begin{array}{lll}81 & 80 & 80\end{array}$

$\begin{array}{llllll}78 & 77 & 77 & 76 & 75 & 74\end{array}$

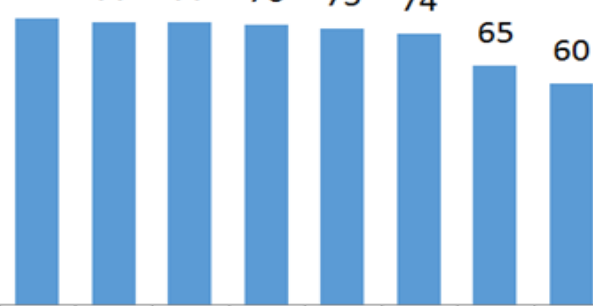

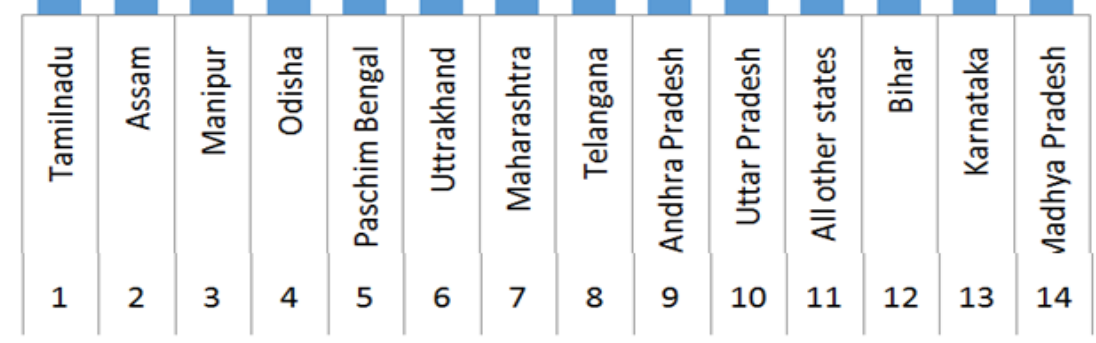

States 


\section{International Advanced Research Journal in Science, Engineering and Technology}

Vol. 5, Issue 11, November 2018

\section{State wise average number of beneficiaries per SSH}

State wise average number of beneficiaries per SSH is presented in the table-. The average number of beneficiaries per SSH is found to be high the states of Tamil Nadu, Assam and Manipur, which is 96 persons on an average of each state. However, in the states like Karnataka and Madhya Pradesh the average number of persons benefited per SSH is found to be low with 65 and 60 persons each. Further, the average number of persons benefited in the states of Odisha is 81 , Paschim Bangal is 80 and Uttarakhand is 80 persons per SSH each. Even though, the number of SSH is found to be low in the state of Manipur with 5 home (2\% of the total homes), the average number of beneficiaries per SSH is fund to be high with 96. Whereas in the case of Andhra Pradesh the average number of persons benefited under SSH is 77 persons.

\section{Major Initiatives}

Orientation Training Programme for Field Officers: An Orientation Training Programme for the newly recruited Field Officers was conducted in the office of the Central Social Welfare Board on 20th July, 2015. The field officers were guided for maximum use of technology for quick and prompt response. It is also emphasised that the inspection reports and pre-funding appraisal reports which give complete picture of the activities being undertaken by the voluntary organizations, must be accurate and precise. The house was also appraised about e-office and its importance.

Interactive meet with NGOs: An interactive meeting under the Chairpersonship of Economic Adviser, MWCD with 24 NGOs representing seven States i.e. Delhi, Uttar Pradesh, Uttarakhand, Chandigarh, Punjab, Haryana and Rajasthan was held on 29th July, 2015 to review the status of programmes i.e. Family Counselling Centre, Rajiv Gandhi National Crèche Scheme and Short Stay Home being implemented through Central Social Welfare Board. The meeting was focussed on the component of the schemes and the problems and challenges being faced by the NGOs in implementing the various programmes.

Training Programme on e-Office A training programme on e-office was organised in the office of Central Social Welfare Board on $22^{\text {nd }}$ July, 2015 for the offices working under the Ministry of Women \& Child Development.

Details of funds allocated, sanctioned, released and beneficiaries covered under the SSH programme during 2001-02 and 2015-16 are presented in the table-. The budget allocation for short stay homes for 2002-2003 under both Plan and Non-plan was Rs.1784 lakh. An amount of Rs.751.76 lakh was released to 289 short stay homes till 31 December 2002. This also includes 39 new short stay homes. An amount of Rs.1589.90 has been sanctioned and Rs.1507.06 was released for 341 Short Stay Homes all over the country during the year 2003-04 during 2004-05, an amount of Rs.1019.57 lakhs was released to these Homes up to 31-12-2004. During the year 2004-05, financial assistance has been provided for the maintenance of 272 Short Stay Homes all over India as on 31-12-2004. The number of short stay homes in operation is 342 . Swadhar Shelter homes scheme is run directly by the Ministry. The scheme of Short Stay Homes is implemented through CSWB. During 2006-07 Rs.1750 lakhs is allocated and an amount of Rs.1247.47 lakhs released to voluntary organizations as on 6.2.2007. The budget allocation of Short Stay Homes for 2005- 06 was Rs.1650 lakhs and an amount of Rs.1649.45 lakhs was released to 339 Short Stay Homes. During the year 2006-07, Rs.1750 lakhs is allocated and an amount of Rs.1247.47 lakhs has been released to voluntary organizations as on 6th February 2007.

A total number of 304 Homes have been sanctioned benefiting 40100 women, an amount of Rs.222.16 lakh (as on 3112-2007) has been released for running the above Homes. The scheme has an inbuilt component of $10 \%$ increase for rent every year and $15 \%$ under maintenance of inmates every 3 years. Therefore, allocation has been enhanced in 201011 to liquidate the liabilities and to release funds to functional homes according to the approved budget of the scheme. About $60 \%$ homes are functional in six major states of Andhra Pradesh, Maharashtra, Orissa, Tamil Nadu, Uttar Pradesh and West Bengal. The focus during the period was to strengthen monitoring mechanism to ensure quality services to the needy women through genuine organizations. Therefore, during 2010-11 continuation grants have been approved for 294 homes; 14 Homes have been closed as their performance was not reported to be according to the norms of the scheme; notices have been issued to 21 Homes giving them an opportunity for improving their services and the remaining cases are under process.

\section{Women's Helpline}

Recognising that women in distress and difficult circumstances require immediate access to assistance and may not have recourse to or information about the availability of such support services, it is proposed to work towards the creation of a universalised women's helpline. Although women's helplines have been set up under the Swadhar scheme in collaboration with several NGOs, and several private organisations and NGOs working on women's issues have also undertaken initiatives to provide such an information and referral service to women facing violence within the home as well as outside, these attempts have been sporadic and city-centric due to the limitations of outreach and resources. There is therefore, a need for standardization of services, documentation systems, trained staff and monitoring and evaluation of such an intervention in a systematic manner. The Committee on Empowerment of Women, in its review of the Swadhar scheme in 2004-05 suggested that because the women's helplines constitute an important component of the Swadhar scheme, this intervention needs to be upscale and standardised with a provision 


\title{
International Advanced Research Journal in Science, Engineering and Technology
}

\author{
Vol. 5, Issue 11, November 2018
}

for documentation, advocacy and capacity-building in a systematic manner. In the next five years, it would be the Ministry's priority to develop a comprehensive proposal for creation of a Women's helpline across the country.

\section{SUMMARY}

Even though the Constitution of India is one of the finest equality documents in the world to protect women and women's rights there are numerous crimes were committed against women in India. Official reports shows that, Sexual harassment cases are growing at 1.09 percent, Sexual abuse cases are growing at 8.89 percent, kidnapping cases are growing at 14.12 percent rate per annum. Dowry Prohibition Act., cases are growing at 10.83 percent, Dowry Death cases are growing at 0.95 percent and the cases under Cruelty by Husband are growing at 7.25 percent per annum during 2005 to 2015. Out of the total crimes that have taken place in India, 36 percent of the cases are Cruelty by Husband, 26 percent of the cases are assault on women and 19 percent are kidnapping. depicts the crime wise distribution of Whereas in the case of Andhra Pradesh out of the total crimes against women nearly 40 percent of the cases are Cruelty by Husband, 30 percent of the cases are assault on women and 15 percent of the cases are sexual abuse during year 2015-16. Andhra Pradesh state registered 25.33 percent share in the total sexual abuse/ modesty of women cases in India during 2015-16. Out of the number of sexual harassments cases reported in Andhra Pradesh (7196 in 2015), the most number of sexual harassment cases were reported in Guntur District with 1204 cases followed by Krishna District with 1077 cases and East Godavari with 729 cases. It became visible that the number of dowry deaths case is under control, which was 173 cases in 2006 and 273 cases in 2010, further it reduced to 215 cases in 2014.

Many of those were remained destitute and still government taking the remedial measures to prevent women fall into the destitution traps. Short Stay Homes are set up with an objective to rehabilitate the women in distress into the main stream of society and empower them psychologically as well as with skills to lead independent normal life. Rehabilitation and follow-up are vital components of the scheme. Women are looked after through follow-up even after they are relieved from the Short Stay Home. An amount of 2038.95 crore has been sanctioned to maintain 247 Short stay homes and provided 23712 destitute women shelter during 2016. The number of SSH are decaling from 384 in 2009 to 283 in 2015 . Whereas, number of destitute women who provided shelter is 27648 in 2009 and 27168 in 2015 which is not a major decline. Further, the number of home were reduced to 247 and as beneficiaries declined to 23712 in 2016.

In India, about 23712 persons are benefited in SSHs programme during 2015-16. Out of the total, most number of destitute women are in the states of Tamil Nadu with 3072 persons, followed by Odisha and Uttar Pradesh with 2592 persons each. Although, Andhra Pradesh state registered 25.33 percent in the total sexual abuse cases, 8.42 percent share in internal traffic Prevention Act, 5.60 percent share in assault of women with intent and 5.40 percent share in Cruelty by husband, only 1152 persons have joined in the SSH. This clearly shows that there is a wide gap between trap and cure. Average number of beneficiaries per SSH is found to be high the states of Tamil Nadu, Assam and Manipur, which is 96 persons on an average of each state. Whereas in the case of Andhra Pradesh the average number of persons benefited under SSH is 77 persons.

\section{CONCLUSION}

At most there is a need to revise financial norms of 'Swadhar Greh' in order to reach out to those women who are victims of different circumstances and are in need of institutional support for rehabilitation so that they could lead their life with dignity. And all the state Governments have been requested to review the performance of the existing shelter homes for its conversion to Swadhar Greh. Further, more micro level studies need to spotlight on insights into the destitution sources and also need to describe the factors that influencing the working poor to fall into the destitution traps.

\section{REFERENCES}

[1]. Planning Commission (Ed.), Important issues on Ageing in India Recommendations to Planning Commission-Will social improvements for elderly grow by 8 percent?, Available at http://planningcommission.nic.in/data/ngo/csw/csw_15.pdf, accessed on $15^{\text {th }}$ November 2015 .

[2]. Rao, M.K. (2005) Empowerment of Women in India New Delhi: Discovery Publishing House.

[3]. Devereux, S. (2003). Conceptualising destitution, Institute of Development Studies.

[4]. Harriss-White, B. (2002, June). A note on destitution. In The Dissemination Workshop of the NCAER/QEH/DFID Project on Alternative Conceptualisations of Poverty, NCAER, New Delhi, April. 